\title{
FERNANDO DE ROJAS' PESSIMISM: THE FOUR STAGES OF LIFE FOR WOMEN AT THE MARGIN
}

\author{
Robert L. Hathaway \\ Colgate University
}

First published as the Comedia de Calisto $y$ Melibea, then as the Tragicomedia de Calisto y Melibea, Fernando de Rojas's only literary work and a masterpiece of the early Renaissance in Spain soon became known as Celestina due to the immediate popular interest in the central character, a crafty and even diabolical old trafficker in flesh, in appropriate recognition of "her living domination of the work" (Gilman 82). ${ }^{1}$ Over

1 Shipley's remarks bear repetition here: "All of those around Celestina succumb to her influence, and many respect her, for all long to share the faith and confidence in the worth of individual experience that she has promoted for decades, long has embodied to perfection, and has sought to institutionalize. Even many of us in her extended audience, noting her superior understanding of self and nature, are persuaded not to judge her severely, as had the enforcers of the old order in her community (who three times, at least, tarred and feathered her, 77), but to venerate her as a numinous Earth Mother ('más que mujer,' in Calisto's words, 112), the terribly attractive incamation and agent of forces that move us all" (100). Morón Arroyo agrees with this last point: the reader may first of all recall Celestina as "la humorística. Celestina la buena, que procura placer al hombre necesitado, porque así nos hizo Dios" (97).

With the title "Femando de Rojas's Celestina: The Pessimistic Life Stages of Women at the Margin," a very much shorter all-English version of this study was read at the "On the Margin" conference of the Center for Medieval and Early Renaissance Studies at Binghamton University on 15 October 1993. I am indebted to three students in my Spring 1993 Spanish Renaissance seminar - Constance Bartlett, Rebecca Goodman, and Megan Kenny - for informal feminist conversations which helped me to focus my approach. 
the centuries its author has received much critical praise for his groundbreaking presentation of the female characters; an appropriate example is this statement by Swietlicki: "Rojas does not treat the function of women as a moral issue, but rather portrays women as realistic individuals in a variety of social roles in which they demonstrate unprecedented forcefulness and rebelliousness" (10). ${ }^{2}$ And Celestina herself marks a profound change in the literary depiction of the Hispanic bawd, as Márquez Villanueva has amply shown in a recent study: "Fue sólo Fernando de Rojas quien, tras sus muchos avatares en ambos extremos del mundo medieval, transformó por primera vez a la alcahueta en un personaje universal a la par que siniestro" (140).

There are five women whose personalities and actions gave rise to Swietlicki's description, all but one of them socioeconomically marginalized. It is these four on whom I shall principally comment, but only after a brief look at Melibea, the high-born woman of means whose carnally-inspired protofeminism is perceived as bearing the stamp of womanly reality; here is her cri de coeur in act ten:

¡Oh lastimada de mí! ¡Oh mal proveída doncella! ¿Y no me fuera mejor conceder su petición y demanda ayer a Celestina, cuando de parte de aquel señor, cuya vista me cautivó, me fue rogado, y contentarle a él y sanar a mí [...]? [...] ¡Oh soberano Dios: a ti, que todos los atribulados llaman, los apasionados piden remedio, los llagados medecina; a ti, que los cielos, mar [y] tierra con los infernales centros obedecen; a ti, el cual todas las cosas a los hombres sojuzgaste, humildemente suplico: des a mi herido corazón sufrimiento a paciencia, con que mi terrible pasión pueda disimular! [...] ¡Oh género femíneo, encogido y frágil! ¿Por qué no fue también a las hembras concedido poder descubrir su congojoso y

2 His artistry is not restricted to the women: "Rojas reveals a remarkable psychological penetration into a whole range of character, and his art of revealing this little by little, showing us even the gestures and actions of the people we meet by means of descriptive details slipped into the dialogue, adds strength to our impression that the world he shows us is the concrete world of time and space" (Coupe et al 326). On Rojas's awareness of the world of prostitution see Lacarra 1992, 274-77. 
ardiente amor, como a los varones? Que ni Calisto viviera quejoso ni yo penada. $(X: 153-54)^{3}$

The constraints of modesty and forbearance which society has prudently mandated are clearly brought into question; the underlying potency of personal desires is passionately evident. Van Beysterveldt points out that "la honestidad de Melibea representa una actitud socialmente condicionada: no se la puede considerar de ningún modo como una expresión de la intimidad moral de su persona" (99). Ultimately this maiden will have her Calisto for, as Sears observes, "the walls society builds around the virgin daughter are only as strong as her own resolve" (98), and Melibea's resolve is strong only for lying with Calisto. She must feign innocence because it is expected of her as a dutiful daughter of the upper bourgeoisie. To be sure, her sexuality is blindly ignored by her parents: the father Pleberio a self-important man of business, the mother Alisa more socially active than maternally perceptive. During the course of the Tragicomedia they agree not to mention to Melibea the subject of marriage because she could not know anything about procreation; Alisa remonstrates her husband: " $¿ Y$ piensas que sabe ella qué cosa sean hombres? ¿Si se casan o qué es casar? ¿O que del ayuntamiento de marido y mujer se procreen los hijos? ¿Piensas que su virginidad simple le acarrea torpe deseo de lo que no conoce ni ha entendido jamás? ¿Piensas que sabe errar aun con el pensamiento?" (XVI:207). ${ }^{4}$ How devastatingly, even caustically ironic that at the time

3 When the occasion later arises, Melibea is intent on her pleasure, but not to the extent characterized by Beltrán: "parece olvidar sin demasiadas dificultades el hecho de que Lucrecia está siendo testigo del espectáculo de su desfloración" (3); whereas Calisto would have witnesses to his gloria, Melibea will not: "Yo no los quiero de mi yerro" (XIV:191; we must assume that Lucrecia at this moment obeys the prior command "Apártate allá").

I use the Libros del Bolsillo edition prepared by Dorothy $\mathrm{S}$. Severin (Madrid: Alianza Editorial, 1969, reimp. 1989), respecting her markings indicating the various texts (see her p. 32) and indicating both act and page as here, continuous underlinings indicating the intercalations of the Tragicomedia; unidentified quotations are from the same page as the preceding.

- Grieve writes that as a maternal character Alisa "barely emerges: her seeming obliviousness to the purpose of Celestina's visit to Melibea shows her either to be ignorant and unconcerned, to be guilty of negligence, perhaps, since everyone in the town seem to know the business of Celestina" (352). Lacarra also cites her ignorance and notes that her "excesivo orgullo la lleva a atribuirse la pretendida conducta virtuosa de la hija: "Que yo sé bien lo que tengo criado en mi guardada hija" [...]. Con estas palabras confirma, irónicamente, el deber que 
of this conversation Melibea has already eagerly surrendered her virginity! And just as eagerly will she commit suicide after Calisto's death in order that she may lie with him forever: she begs her father "que sean juntas nuestras sepulturas" (XX:230).

This affair was brought to its coital satisfaction by the intervention of the bawd Celestina, with the attendant reduction of all honesty and sentiment to the level of deceit and harlotry. Although both Calisto and Melibea mouth the hoary conceits and clichés of courtly love, amour lointain is the thing farthest from their minds. Socially elite though they may be, the great common denominator of sex brings them down to the animal level of human interaction, lowered from the height of social esteem to the steamy equality of copulation. In Rojas's world of completely self-centered and self-serving men and women there are no longer any superiors or inferiors. Calisto and Melibea are in sum no better than their servants.

For the women on the margins of this very hierarchical society of Catholic Spain at the close of the fifteenth century their sex may very well have seemed to be the means for gaining, if not freedom, at least some measure of self-determination in the dream of independence. The only character in this most basely human of dramas who operates across all classes, civil and ecclesiastical, is Celestina, that great lustful character who does command our admiration despite her venial sins and practices. There are other women who aspire to such freedom and who come from the servant class as did she, but like her they too are doomed to frustration if not violent death, such is the pessimism which pervades Rojas's creation of his characters. And if, as I posit, Celestina is the fourth and final of Rojas's stages, the first three will be shown to be, in the order of their decline, Lucrecia, Areúsa, and Elicia.

Deyermond identifies four "more or less autonomous female microsocieties [...]: the convent, the brothel, the widow's household, and the court or household temporarily ruled by a woman in her husband's absence [...]," defining Celestina's brothel as an "authentic female microsociety." He notes further that "the four types [...] have widely differing degrees of permanence, stability, and autonomy" (1993, 2 and 4). The four women named above inhabit or wish to (Lucrecia) that one illicit microsociety, that which, because it involves clandestine prostitution, is the most precarious in terms of security - and even

como madre tiene de educar y guardar a su hija y muestra su irresponsabilidad en hacerlo" (196-97). 
hope. Lacarra provides documentary evidence that Celestina reveals close ties to the actual situation of prostitution in Salamanca at the close of the fifteenth century (1993, especially 46-48), and aptly describes its very real pitfalls. $^{5}$

1. LUCRECIA. Lucrecia is Melibea's handmaiden and "a stereotype of the servant on which upper-class society depends" (Rank 227). We first see her when she is too embarrassed to state aloud Celestina's name in announcing the bawd's first appearance in Pleberio's house: she knows well who she is and what the visit may portend; with that knowledge she later protests about the fleshmonger's dealing with Melibea. She is bought off, however, with a promise: "Irás a casa y darte he una lejía, con que pares esos cabellos más que el oro. [...] Y aun darte he unos polvos para quitarte ese olor de la boca, que te huele un poco [...]" (IV:101). Lucrecia is thankful: " $i O h$, Dios te dé buena vejez, que más necesidad tenía de todo eso que de comer!," a clear expression in the Tragicomedia of her incipient preference for companionship over sustenance, an indication that she is, in Gilman's two phrases, "timidly envious of the joys and irresponsibilities of prostitution" and given to "slightly sordid dreaming" (62 and 63) ${ }^{6}$ Celestina's request that she not be an obstacle is one which also elliptically offers future assistance: "Calla, que no sabes si me habrás menester en cosa de más importancia" (IV:101); one can rightfully assume that cosa will have to do with one or

${ }^{5}$ Lacarra states that due to the concern with doing away with the prostitutas encubiertas (Areúsa alone, and Elicia as the last in Celestina's stable), several municipalities tried to compete by providing sexual services in their own ramerias: "Alegaban [some cities] que eran necesarias para eliminar de una vez por todas la prostitución clandestina, pues proporcionarían 'mugeres de mas calidad' a los 'hombres honorables' que se veían obligados a utilizar sus servicios por ser para ellos una deshonra acudir con el común a la mancebía pública" $(1993,46)$. There was a profit motive as well: "aunque no por ello menos importante, proporcionará [the establishment of mancebias] tanto a los municipios como a la Corona una apreciable fuente de ingresos con que paliar sus graves problemas económicos" (1992, 272). See also Márquez Villanueva, pp. 130-37.

6 See Bataillon: Lucrecia is a "personnage qui va être longuement muet, mais tout oreilles" (157). Commenting on the ordering of her priorities, Eaton writes that "Rojas twice has Lucrecia use the metaphor of going without food to convey her greedy eagerness [the second is in IX:152: "así me estuviera un año sin comer, escuchándote y pensando en aquella vida buena" of a prostitute] [...]. It is in keeping with Lucrecia's limited vocabulary and imagination that she would tend to repeat certain hackneyed phrases to express her emotions" (221, with noted reference to Lida de Malkiel [643-44] on this unimaginativeness). 
another of her other arts. In keeping silent, Lucrecia's attitude may be interpreted not only as an understanding of the implication but also as an implied affirmative response and thereby a capitulation.

This request in the Tragicomedia ties in with the development of Lucrecia's character in the added auctos. As witness to her mistress's amours Lucrecia does become increasingly interested in some such "cure" for herself. Maravall has described the change: "Esta criada, que empieza siéndolo en el sentido más tradicional, y, por tanto, sobre la base misma de un nexo familiar con la casa, muestra progresivamente su despego por su ama, se deja llevar a una complicidad fríamente consentida con el vicio y revela atracción por el placer desordenado, concupiscencia, egoísmo, todo ello desde el punto de vista del criterio moral vigente" (86). Ultimately, as Deyermond comments, she acts like a woman whose sexual desires, inflamed by the scenes of love which in the Tragicomedia she has witnessed or heard for a month, can no longer be bridled (8): so heated is she that at one point she catches Calisto up in her arms, causing Melibea to complain: "Lucrecia, ¿qué sientes, amiga? ¿Tórnaste loca de placer? Déjamele, no me le despedaces, no le trabajes sus miembros con tus pesados abrazos. Déjame gozar lo que es mío, no me ocupes mi placer" (XIX:222). With good reason Eaton writes that "it is difficult to dismiss Lucrecia's embrace as a mere friendly greeting" (224); certainly her erotic yearnings have increased, for moments later, overhearing the lovemaking, she says in an aside " $¿ V i d a$ es ésta? ¿Que me esté yo deshaciendo de dentera y ella esquivándose porque le truequen! [...] Pero también me lo haría yo, si estos necios de sus criados [Tristán and Sosia] me hablasen entre día; pero esperan que los tengo de ir a buscar" (XIX:223).?

Lucrecia is, then, at the first stage of the decline and fall of the marginal female: in the pre-text apparently honest and faithful, full of good will and not terribly mindful of her social and personal

${ }^{7}$ In act XIX, Lucrecia becomes a sort of alter-ego of Melibea, and her embrace of Calisto reflects this role. "She expresses directly, both by words and action, the sexual desires which Melibea still feels it necessary to express obliquely," as the comparison of their songs makes clear, Lucrecia's "shot through with images of lust" and Melibea's reflecting "her sentimental idea of love" (Eaton 224). This is, for me, too romanticized an interpretation of the mistress (cf. n11 below); I agree with Beltrán's more forthright description: "La escena chorrea sensualidad, y toda la pone Melibea, hasta el punto de que Lucrecia, completamente en celo, y no pudiendo resistir más, se arroja sobre Calisto para llenarse del placer que pueda" (10). Lacarra examines the songs in some detail (1990, 84-85), linking them with well-used symbols of lust. 
dependence, she starts to long for the pleasures which her femininity comes increasingly to demand, inflamed by the example of her mistress, pleasures which require some freedom from the yoke of service (Celestina says of her that "su mucho encerramiento le impide el gozo de su mocedad" [IX:148]). Although her character is not fully developed, she is an individual in the process of change brought on by circumstance; as such she is a counterpart to Pármeno, he too brought to ground by the prospect of sexual satisfaction. Round writes that Rojas "presses home the paradox that values can actually be undermined and supplanted. He does so most obviously through the brothel scenes, with their implied reduction of all human pretensions to the same sordid level" (51); though perhaps not as obvious, the example of Lucrecia clearly illustrates the process: "El autor nos señala de dónde procede la maldad de Lucrecia: del hedonismo o más exactamente, del interés por lo sensual" (Okamura $55)^{8}$

2. AREUSA. These four women have structural as well as thematic relationships: "Lucrecia, for example, in her capacity as foil to Areúsa, heightens the latter's portrait as a captivating fille de joie" (Kish 98). Already become a prostitute, Areúsa is at first a kept woman who has been living with only one man. We are to believe that in all honesty she has been striving to keep up honorable appearances; ${ }^{y}$ how short-

${ }^{8}$ Okamura lists the stages in the trajectory of her awakening hedonism (5556, text and notes 6 and 7). Mariscal de Rhett states that Lucrecia "está obligada a depender de la beneficencia de sus amos para obtener marido" (113), but this refers to the traditional servanthood. Why times have changed is discussed by Rodríguez-Puértolas (1976, 158-62); the impact is wonderfully illustrated in Areúsa's diatribe treated below and in Mariscal de Rhett's continuing remarks leading to the conclusion that "sólo le quedaria a Lucrecia la alternativa de abandonar esa posición y adoptar la de sus primas" (114). I maintain that the attraction of sexual satisfaction is activated by the Calisto-Melibea amorio and has its origen in the person and not in any socioeconomic oppression.

9 Lacarra cites a Salamancan document, "De la casa dela mançeuia, cantoneras y mugeres publicas" of 30 October 1585, in which one reference, mutatis mutandis, could have been describing Areúsa: "ai muchas mugeres en la dicha mançeuia que tienen palaçios alquilados fuera della donde se uan de noche a dormir con hombres finxiendo ser mugeres de mas calidad" (69, item 13).

Her 1993 article has an error which should be corrected: "La distinción entre putas públicas y encubiertas se fundamentaba en sus ingresos, sin duda sustancialmente superiores para las primeras $[. .$. ]" (39, my emphasis), whereas on 
lived this is becomes clear in Sosia's description of her after Celestina's death: "una hermosa mujer, muy graciosa y fresca, enamorada, medio ramera; pero no se tiene por poco dichoso quien la alcanza tener por amiga sin grande escote" (XV:203), the implied high price an indication that she is prized by her clients. Conversing with Pármeno and seeking some means to woo him from his loyalty to Calisto, Celestina discovers this youngster's infatuation with this sensual creature for whom he has hungered; she "tantalises him with the prospect of pleasures desired but as yet unattained" and "presents him with his first chance of trying his virility" (Hawking 181, 188). Celestina visits Areúsa to propose that she take up with Parmeno and finds her abed with the mal de madre. As a surefire cure the bawd prescribes sex; when Areúsa feigns not to understand, Celestina counters with " $i$ Anda, que bien me entiendes, no te hagas boba!," provoking this response: " $\mathrm{i} Y a$, ya; mala landre me mate, si te entendía! ¿Pèro qué quieres que haga?. Sabes que se partió ayer aquel mi amigo con su capitán a la guerra. ¿Había de hacerle ruindad?" (VII:128). Despite professed fears of neighbors' tongues ("ciertos barruntos de honestidad," [Lida de Malkiel 675]) she is very soon after taking the cure.

In the Tragicomedia Areúsa is shown to be even more of a strongminded young woman, fiercely jealous of what she perceives as a certain independence and viciously eager to avenge the death of Pármeno for whom, she claims, she had come to feel real affection. But she who was "semi-independent" continued bedding with Pármeno (see Sosia's comment on the "más de tres noches malas" he had with her [XV:197]) ${ }^{10}$ and joined Celestina's table; in the Tragicomedia she is beholden also to the rufián Centurio. Lida de Malkiel does point out her "entendimiento e imaginación" and sees her characterized by Rojas "como personaje que

continuation in the same paragraph we learn that the públicas earned twelve maravedis while the encubiertas earned as much as thirty to fifty. On the income distinctions among the encubiertas themselves, see her 1992 article, 272-73; one wonders if such distinctions had any sort of influence on the characterizations of Areúsa and Elicia.

10 Sosia's comment apparently went unnoticed by Stamm: "Lo que más le molesta a Areúsa - y esto es poco inverosímil, dadas las circunstancias de $s u$ única noche de amor y el hecho de que apenas reconoce la presencia de él en el banquete - es la muerte de Pármeno" (161, my emphasis). 
teóricamente más se complace en el libre ejercicio de su voluntad" $(671),{ }^{11}$ traits which permit one to project the intelligence and strengths to stand on her own feet, to plan bloody vengeance, to trick a dense Sosia with some facility. ${ }^{12}$ And she speaks for her creator, Castro contends: "Areúsa no es "la prostituta", sino la mujer que piensa y expresa las razones que le mueven a vivir como tal, razones que importaban mucho a Rojas, y por lo mismo amplifica en la [Tragicomedia]. De la narración y descripción de lo típico y enmarcado, se pasa a la expresión de las vivencias del propio vivir, que Areúsa expresa en primera, no en tercera persona: "Por esto, madre, he querido más bivir en mi pequeña casa [...], no en la grande de su señora" (142, Castro's emphases). And even though in the Comedia, in her first meeting with Pármeno at Celestina's insistence, "elle se défend d'être une Elicia" (Bataillon 153), she becomes one over the course of the Tragicomedia. What I believe one must project for her future, then, is that the need for her daily bread can only lead, as it has done with Elicia, to ever more dependence bought at the cost of her body; recall the plurality of lovers implicit in Sosia's description above.

The link between Lucrecia and Areúsa is also manifest in the Tragicomedia, in the latter's vehemently acid description (alluded to earlier) of what it's like to be a servant. Her words appear to be born directly in bitter experience and thus are testimony to Rojas's perceptive observations of his society. Her opening salvo echoes Lucrecia's

11 Lida de Malkiel continues her comments on Areúsa's diatribe directed against señoras (I comment on them below): "La verbosa elocuencia y el acopio de detalles imaginativos, de indudable abolengo talaverano, van encabezados y remachados con máximas que insisten en el valor absoluto de la libertad y que son peculiares de Areúsa y de ninguna otra criatura de Rojas" (671, my emphasis). Only if the reader, then, expects to find in Areúsa merely a stereotype will there be any reason to be baffled by her character (cf. Ricapito 185-86).

12 Gilman states that "in these added acts Areúsa has become a model for the designing courtesan, the perfect intrigante" (203). Stamm describes her approach: "Las mañas que Areúsa emplea con el rascacaballos demuestran un lado de su carácter que no habíamos visto. Su técnica es suave y graciosa, perfectamente adecuada al sujeto con quien está tratando. Como dice ella, "otra arte es ésta que la de Celestina». Con todo, su estratagema es transparente: halagos, fingido amor y preocupación por el bien de su rústico galán" (167). Lacarra points out, however, that, despite her evident talents, as a prostituta clandestina she has lost much of her self-determination and "no parece probable que sea capaz de superar a Celestina con sus nuevas artes" (1990, 88; see pp. 23-29 and 88-90 for more description of the world of prostitution and municipal efforts to control it). 
complaint: "Así goce de mí, que es verdad, que éstas, que sirven a señoras, ni gozan deleite ni conocen los dulces premios de amor" (IX:14849); with good reason does Deyermond refer to her as the "ideologist of the microsociety" $(1993,15)$. She goes on to repeat the naggings and recriminations which are part and parcel of the handmaiden's life in this new society where the bond between master and servant, as Lihani says, "was one based on economic necessity and on greed, rather than on fondness and altruism" as in former times (21). She gets to the subject of sex: "Y cuando ven cerca la obligación de casallas, levántenles un caramillo que se echan con el mozo o con el hijo o pídenles celos del marido o que meten hombres en casa o que hurtó la taza o perdió el anillo" (IX:149). After providing more illustration of her theme she closes with the statement Castro adduced: "Por esto, madre, he querido más vivir en mi pequeña casa, exenta y señora, que no en sus ricos palacios sojuzgada y cativa" (IX:150).

Mariscal de Rhett comments that Areúsa "vive convencida de la superioridad de su posición como mujer mantenida, posición que, en contraste con la vida de servicio, le permite desarrollarse como individuo, ya que la vida de servicio niega la individualidad de la persona, pues no son tratadas las que sirven más que en forma genérica" (118, though this last is not strictly true of the early Lucrecia). Such conviction, however, is misplaced, as over the course of its brief development the Tragicomedia illustrates. ${ }^{13}$ Rank gives us a fine summing-up: Areúsa "is totally aware of the nature of the exploitation of her peers, but $[. .$.$] not necessarily aware of the nature of her own.$ Her inevitable subjugation to the upper classes is, ironically, grounded in what she views as her freedom from the master. What she seeks is an economic independence which allows her a life that has no precedent except in the patterns established by the upper classes" (231). Left alone and to her own devices again by the death of Pármeno she still shows a will sufficient - perhaps - to allow her to become another Celestina, but that future is, as has been said, dark and none too promising: her

13 Rodríguez-Puértolas properly disagrees (1976, 148-50) with Castro's statement that only among the servants does one find "rumores esperanzados de un futuro mejor" (156); rather, he says, "lo cierto es que en La Celestina todo intento de realización de la persona y de entendimiento y comunicación están irremisiblemente abocados al fracaso, como los individuos mismos lo están a la destrucción" $(1976,155)$. Obviously neither he nor I are optimistic. I agree with Deyermond that "Areúsa seems [...] to have the determination and the skill [albeit, I must point out, not all the skills] necessary not only for survival in an uncertain and competitive world, but also for success" $(1993,18)$, but here as throughout the Tragicomedia, I believe, pessimism outweighs characterization. 
relationship with the rufian Centurio surely seems to be that of whore and pimp. In addition to the dependence that implies (Lacarra 1990, 87) we are definitely made aware of a gradual dissolution: Elicia says as she goes to visit her, "Quiera Dios que la halle sola, que jamás está desacompanada de galanes, como buena taberna de borrachos" (XVII:209). If the additional month of lovemaking might have wrought a change in Calisto and Melibea, "a kind of deceleration, a pastoral languor, a sentimental amplitude" (Gilman 205, though not to the detriment of sexuality, it must be stressed), ${ }^{14}$ the same period has allowed the sense of loss to fester in Areúsa and Elicia, affecting each in her own fashion.

Lida de Malkiel presents an insistent discussion (pp. 659-61) of the "transposition" of Elicia and Areúsa in the intercalated acts (XIV, XV, XVII, XVIII) of the Tragicomedia, summing up as follows:

14 Deyermond speaks of the "female sentimental society," "the romantic sisterhood," established by Melibea and Lucrecia (1993, 10-11), but it is as "evanescent" (his adjective) as the bookish daydreamings Calisto creates to wash from his mind the memory of his servants' death and their possibly deleterious effects on his lovemaking; the lovers each take momentary refuge in poetic moonings (acts XIV and XIX) but are ultimately prompted - prodded - by their carnality, and the notion of "deceleration" must be modified to take into account the continuing coitus. Although he did not do so, Friedman might well have included Calisto in his characterization of Melibea as "trapped in society, in psychological contradictions, in language" (368).

The idea of a subtle change in genre in the intercalated acts is, for me, a bit difficult to accept without question or modification: "in the absence of Celestina the continuing intrigue carried on by Elicia and Areusa tends towards the theatrical and the purely comic - with all the jesting, typification, and scenic maneuver thereby implied" (Gilman 205). Certainly it includes a miles gloriosus - "Centurio est une création si délectable pour le public d'alors qu'il donne son nom à l'addition de 1502" (Bataillon 135); in his study of "Los rufianes de la primera Celestina" Gimber concludes that popular demand influenced the creation of this character: "De la evidente transposición de elementos rufianescos de los pliego sueltos a la Celestina se deduce una demanda de tales escenas por parte de los receptores, explicación suficiente para la adición del Auto de Traso" (75). But the singleminded passion for vengeance is the deadly serious thematic underpinning of Centurio's scenes and I doubt that many receptores forget it, and the rufian's relationship with Areúsa serves to characterize her decline. Celestina's explanation of the "loss" of the gold chain - "Di a esta loca de Elicia, como vine de tu casa, la cadenilla que traje para que se holgase con ella y no se puede acordar dónde la puso" (XII:181) - is such a transparent lie that it may cause a smile, but only a brief one, given the context of violent clashing of wills. 
Si dentro de nuestra total ignorancia de la composición de La Celestina y de la relación entre el texto primitivo y el intercalado, vale la pena formular conjeturas, lo menos aventurado es suponer una distracción del "interpolador" en el manejo de los nombres y álgunas circunstancias de las dos mochachas: al señalársele su error, quizá demasiado tarde para poder subsanarlo, intentó salir del paso sosteniendo antes que enmendando su desacierto. Sea como fuere, desde el punto de vista del carácter, la continuidad entre la Elicia del texto primitivo y la Areúsa de los actos XIV, XV, XVII y XVIII, así como entre la Areúsa del texto primitivo y la Elicia de dichos actos es tan obvia que se impone descartar el trueque de los nombres y tomar en cuenta la unidad de los personajes. (661)

3. ELICIA. Rather more adventuresome, less routine-bound, ${ }^{15}$ I propose that the trauma of the death of Celestina has left Elicia without direction and protection; she had always depended upon the bawd's ingenuity, even in the famous tricking of Sempronio which would surely have failed if Celestina had not been there to make the lie work. Furthermore Elicia shunned learning some of the skills which her "mother" could have taught her, as Lida de Malkiel points out: "se aparta de los hechizos que ocupan a Celestina y se resiste a aprender una de sus habilidades más sonadas. Sacar partido de su atractivo es toda su vocación" (666, my emphasis). As for any change in Areúsa, I agree with Stamm's refutation: "Es imposible decir que haya habido un cambio radical en el carácter de Areúsa en los actos adicionales sencillamente porque no la hemos visto anteriormente en su vida todos los días. En el acto VII la encontramos enferma, molesta, acostada, sorprendida por las importunas demandas de Celestina, defendiéndose como mejor podía, cediendo al final; luego en garde en el banquete, y muy empeñada en establecer una visión pública de sus sentimientos acerca de la independencia" (161; cf. also 164).

15 See Lida de Malkiel: “es Areúsa una creación de sorpreṇdente originalidad, tan alejada del esquema convencional de la cortesana, que por eso mismo no se le ha hecho debida justicia, pues como a Melibea, igualmente alejada del esquema convencional de la doncella, los críticos la han juzgado por la falsilla de su propia rutina" (676). These pages represent another of those "repetidos asaltos a un inconquistable hermetismo" which Márquez Villanueva states as the form of Celestina criticism over the years (18). 
Elicia herself lacks, Rank says, "the decisive, active quality which characterizes Areusa" (232). ${ }^{16}$ Sexual partner to many men, beguiler of the truly hapless Sempronio, pleasure is her only goal: "Que uno en la cama y otro en la puerta y otro, que sospira por ella en su casa, se precia de tener," claims Celestina (VII:129). Her atractivo still facilitates this, but she ignores Celestina's advice that she learn some of those arts which might provide for her later years ("Si no, ahí te estarás toda tu vida, hecha bestia sin oficio ni renta" [VII:133]), particularly refusing to begin stitching up maidenheads; as it ironically turns out, Celestina is the sole practitioner in the city and upon her death the whole tricky business of feigning virginity must cease because Elicia has had no vision of a future: "Mientra hoy tuviéremos de comer, no pensemos en mañana. [...] Gocemos y holguemos, que la vejez pocos la ven y de los que la ven ninguno murió de hambre" (VII:133). Captive to her present (an ironic carpe diem), she will not take the time to acquire those skills which later in life, when the body has lost its charms and capacities, could provide her a living as they have Celestina.

Referring to Celestina's house, Round has stated that "the brothel [...] functions as part of a sex-money continuum, in which lust and monetary greed are instantly interchangeable" (51). Elicia ignores the facts that continuum is not everlasting; that in the future her charms will fade and so also will her clientele; that in the present this brothel depends most importantly on Celestina as its axis, as the central facilitator, the spider in the middle of a vast web of sexual intrigue, as Weinberg has shown (see his graphic representation, 153).

In Gilman's phrase, Elicia is "purposefully limiting herself to the immediacy of impulse" (62). Once the old bawd is killed by Sempronio and Pármeno, she is bereft of support and direction and appears to lose that precarious self-confidence she once showed in deceiving Sempronio - again, with Celestina's all-important aid. In the additional acts of the Tragicomedia we hardly recognize her, so dependent is she now on Areúsa, so sorrowful that her life has changed so radically, so aimless without Celestina and Sempronio, her prop and her puppet: "¿Adónde iré, que pierdo madre, manto y abrigo; pierdo amigo y tal que nunca faltaba de mí marido? ¡Oh Celestina sabia, honrada y autorizada, cuántas faltas me encubrías con tu buen saber!" (XV:201); I find it

16 See Stamm: "Es siempre la débil, rencorosa, falta de imaginación, totalmente incapaz de vivir sobre sí. Muerta Celestina, ¿adónde va? A comunicar las nuevas y a buscar apoyo afectivo, pensando ingenuamente que Areúsa va a compartir su aflicción" (161; cf. Snow 283). 
impossible to put this lament in Areúsa's mouth, as Lida de Malkiel would have us do. ${ }^{17}$

4. CELESTINA. As Ayllón has pointed out, "lo que se destaca en La Celestina muy a menudo es que el placer de la juventud tarda poco en cambiarse en tragedia ya que casi siempre el dolor y el sufrimiento siguen el placer en el mundo de La Celestina" (163). Elicia is at the penultimate stage of Rojas's description of the marginalized woman's "progress," and one may well agree with Marcel Bataillon that she is not prime goods: "Etre confiée à la garde "maternelle» de Célestine ne qualifie guère moins clairment une femme que d'être sous la tutelle du padre de la mancebia" (149). She does spurn Areúsa's offer to shelter her, however, and will continue on in Celestina's house; the rent has been paid and she may make some money keeping it open for assignations (how much rent, one must wonder). Brancaforte has called the world depicted in Celestina a human hell which portrays the dynamic relationships among cupiditas, deception, and violence (7 and 9); it seems to me that Elicia has slid down into just such a hell. ${ }^{18}$

Celestina describes to Sempronio her pride in (and her dependence on) her vocation:

Pocas vírgenes, a Dios gracias, has tú visto en esta ciudad que hayan abierto tienda a vender, de quien yo

17. Castro pays particular attention (99-100) to Sosia's report to Tristán about his meeting with "Elicia," emphasizing the contrast between his own manured shoes and her musk perfume, her snow-white hands: "cuando las sacaba de rato en rato de un guante parecía que se derramaba azahar por casa" (XIX:218); "estas opuestas perspectivas también hacen aparecer a Elicia como una ramera lujosamente vestida" (100), but this detail of a careful toilette also seems more appropriate for Areúsa than for her cousin (one must recall Celestina's praise as she finds Areúsa in bed, “ ¡Ay cómo huele toda la ropa en bulléndote! [VII:126]). Castro accepts, however, the identification of Elicia (132) as the one who seeks out Areúsa's house "por preguntarle si ha ido allá Sosia y lo que con él ha pasado" (XVII:209).

18 Gallo sees Celestina as finding its origin in the "rampant abuse of the precepts of Neoplatonic love by Rojas' pre-Renaissance society": "Throughout the work, as Neoplatonic social values are repeatedly and systematically overturned, not only is the relationship between lovers undermined; but also, ultimately the basic social fiber among all the players is destroyed. The relationships between servants and masters, between adults and youth, between friends, and even between family members - all collapse" (187-88). 
no haya sido corredora de su primer hilado. En naciendo la mochacha, la hago escribir en mi registro, y esto para que yo sepa cuántas se me salen de la red. ¿Qué pensabas, Sempronio? ¿Habíame de mantener del viento? ¿Heredé otra herencia? ¿Tengo otra casa o viña? ¿Conócesme otra hacienda, más de este oficio? ¿De qué como y bebo? ¿De qué visto y calzo? En esta ciudad nacida, en ella criada, manteniendo honra como todo el mundo sabe, ¿conocida pues, no soy? (II:81)

It would be instructive to repeat here what it is that she does do. As a youngster Pármeno lived with Celestina and describes her life for Calisto and for us; if the list of services is familiar, it is possible that the moral tone of his continuing comment - Pármeno has not yet been "converted" - may not have stuck so readily in the memory:

Ella tenía seis oficios, conviene [a] saber: labrandera, perfumera, maestra de hacer afeites y de hacer virgos, alcahueta y un poquito hechicera. Era el primer oficio cobertura de los otros. [...] Asaz era amiga de estudiantes y despenseros y mozos de abades; a éstos vendía ella aquella sangre inocente de las cuitadillas, la cual ligeramente aventuraban en esfuerzo de la restitución que ella les prometía. Subió su hecho a más: que por medio de aquellas comunicaba con las más encerradas, hasta traer a ejecución su propósito [...]. (I:60, my emphasis) ${ }^{19}$

So experienced, so efficient was she, he explains, that "cuando vino por aquí el embajador francés, tres veces vendió por virgen una criada que tenía" (I:62). A prostitute in her youth - every reader remembers Pármeno's description of the famous "«iPuta vieja!»" calls

19 Tapia extrapolates: "Un negocio de amor, pues, montado con género femenino y preferentemente virginal. En él se explotan vírgenes inocentes, vírgenes postizas y vírgenes que desdeñando su virginidad, la sacan al mercado" (200). Márquez Villanueva explains how these oficios place the bawd within her society: "Como profesional indispensable y bien pagado, la alcahueta comparte (mutatis mutandis) con hombres de leyes y médicos el servicio al estrato pudiente en las ciudades a partir del período bajo-medieval. Su verdadero papel se caracteriza en cierto curioso modo como una mezcla de la práctica cotidiana de ambas profesiones" (51). 
which resound through the streets as she passes $(\mathrm{I}: 59)^{20}$ - and then a procuress and witch in her middle and later years: such is the "honorable" life she is so proud to have led!"

For all the sins she has enjoyed or experienced, one is principal in bringing her to her death - greed: ${ }^{22}$ "Desenfadada y desenvuelta, mueve a la alcahueta un gran impulso vital. Nos preguntamos si es la lascivia, la riqueza o el vino la raíz de su actividad. Pese a que ciertas escenas nos presentan la concupiscencia de Celestina aún no extinguida, debatiéndose entre la condición de testigo de goce y añoranzas lúbricas de su mejor edad, el provecho material o la riqueza es móvil básico de

20 Pármeno's lengthy dwelling on this theme is "Un himno social y natural en el que resuena una exclamación simplificada en dos palabras de intensa carga emocional y peyorativa: 'iputa vieja!'. Una sociedad agrupada en torno a la muerte y los regocijos de la vida: entierros, bodas, festejos, etc.; animales de los diversos elementos cósmicos, las herramientas del trabajo, los mismo obreros y artesanos y hasta una piedra contra otra reproducen ese estribillo que adquiere resonancia musical y universal" (Tapia 179).

21 Ayllón's footnote directs the reader to Gilman's p. 179 wherein is found the statement that the "deepest theme" of Celestina is "the tragic predicament of human life struggling for meaning in an alien universe [...]." Gilman cites a good example, Celestina's anger at Areúsa's hesitancy to have her witness the lovemaking with Pármeno: "The sudden violence of Celestina's reaction, a violence which Areusa (as well as the reader) may hardly have expected, is not merely due to disgust with the false display of coyness. It is rather the violence of an offended honor. [...] This is the honor of the officio which with age and experience has come to represent Celestina's life. As a yo she feels herself to exist in terms of a deep sense of honor; as a tú she portrays herself as honorable and demands that others see and treat her appropriately" (86). She has found her meaning and will not abide anything which will undermine or diminish it. The struggle ends when her own avarice overcomes the insight she has gained from experience - overcomes, in a sense, that officio in the name of personal gain and she fails to recognize how deadly menacing is the confrontation with Sempronio and Pármeno; Fothergill-Payne expresses it this way: "embriagada por su éxito, olvida [Celestina] el deliberar y deja de reflejar en "la natura" de la condición humana" (170).

22 "Celestina has two faults [...]: one, of course, is her greed, the other not knowing when to stop" (Hawking 186); the two combine at this scene to bring her to disaster. Hawking sees the misperception of the mother-son relationship with Pármeno as the spark which sets his blood aflame (189-90), a view which, though correct, rather scants Sempronio's rage at being cheated of money he has already counted as his. 
su antifeminismo" (Tapia 187). ${ }^{23}$ All that she has done has been for money, and the rich recompense she received from Calisto is to be hers and hers alone, never mind the promise to share with Sempronio and Pármeno: "Esto tengo yo por oficio y trabajo; vosotros por recreación y deleite. Pues así, no habéis vosotros de haber igual galardón de holgar que yo de penar" (XII:181). That heavy gold chain, those hundred gold coins, have blinded her to the fact that Calisto's servants are in this as she is, only for gain; enraged at her adamant refusal to share, Sempronio stabs her repeatedly, goaded on by Pármeno who is blind to the fact that his new-found "independence" depends - ironically - on the dying Celestina. Elicia explains to Areúsa: "Y como sea de tal cualidad aquel metal, que mientra más bebemos de ello más sed nos pone, con sacrílega hambre, cuando se vido tan rica, alzóse con su ganancia y no quiso dar parte a Sempronio ni a Pármeno de ello, lo cual había quedado entre ellos que partiesen lo que Calisto diese" (XV:200).

Celestina, then, at the fourth stage incorporates the first three represented by the young women we have examined, each of them in her fashion a pawn moved by "the erotic compulsion which dominates [Rojas's] work" (Gilman 125). We can only assume that she began as a Lucrecia, for the text never takes us back that far into her earliest career, but certainly she became convinced early on that coitus was more attractive and better paying than purity. Once entered into the oldest profession she and Claudina, Pármeno's mother, were probably not unlike Areúsa and then Elicia, converts first and adepts later, Celestina surviving by her wits, Claudina gone now but in "un momento de lírica grotesca" (Morón Arroyo 95) remembered fondly: "Su madre e yo, uña y carne; de ella aprendí todo lo mejor que sé de mi oficio" (III:81); the family connection is more explicit for the three young women, for they are all cousins. The business of enabling the follies of others has suffered; she lives much in her own myth (Snow, 286) with only a jar of

23 Tapia refers to Celestina's "antifeminismo" in accord with her characterization of the alcahueta as "enemiga de la mujer" (186) and cites the Libro de buen amor and the Arcipreste de Talavera o Corbacho as well as Celestina as substantiation. Márquez Villanueva's study is indispensable in tracing the development of the alcahueta hispano-oriental in the literature of Spain: "Rojas pisa con un pie el campo de batalla en que ha venido a parar la convivencia tradicional de las tres religiones, a la vez que con el otro se asienta sobre un suelo firmemente humanístico. Su caso sirve, sin embargo, para ilustrar cómo las suertes se hallaban echadas desde muy atrás, así como el juego que la presencia de minorías semíticas había de seguir imponiendo (aun transformado) bajo la mayoría de edad que suponen el advenir del Renacimiento y los tiempos modernos" (190). 
wine for companionship - "en un jarrillo mal pegado me lo traen, que no cabe dos azumbres. Seis veces al dia tengo de salir por mi pecado, con mis canas acuestas a le henchir a la taberna" (IV:93-94) - and the occasional voyeurism to set her thinking about past delights: "Quedaos a Dios," she says to the actively bedded Areúsa and Pármeno, "que voyme solo porque me hacéis dentera con vuestro besar y retozar. Que aun el sabor en las encías me quedó; no le perdí con las muelas" (VII:132).

When we meet her at the beginning of the work to which she has given her name, she has come down in the world, has moved her base of operations, has but one practicante in her clinic for love sickness. Fortune has given her one grand opportunity to recoup and she cannot suspect that it is her last: "creo muy importante ver a Celestina, no sólo como encadenadora de los sucesos de la Tragicomedia, sino también como una parte de una cadena aún más larga; no sólo como raptora sino como victimizada ella también por la ciega e incontrolable Fortuna que, para la visión de Rojas a lo largo de la obra, lo rige todo" (Snow 281).

Ayllón perceives the world which Rojas created in the Tragicomedia as one in which "se nos revela un mundo dominado por el conflicto - un mundo en que la razón y el sentimiento, el amor y la lujuria y la prudencia y la pasión están en conflicto constante y continuo; un mundo en que el hombre está en conflicto consigo mismo, con su prójimo y con el universo. En su lucha con fuerzas universales, el hombre [and woman] surge impotente ante el poder de tales fuerzas como el amor y la fortuna. El conflicto existe en el tema, en los personajes y en la ideología del mundo de La Celestina" (161). Nowhere is the struggle more apparent, the outcome more bleak, the dying more violent, than in the winebibbing old procuress, and Rojas definitely seems to be telling us that her "daughters" can expect no better. Each in her own way may be as forceful and rebellioús as Swietlicki has characterized them, but they are all ultimately impotent and they too will slip from the margin to the hell below. As Rodriguez-Puértolas aptly described it, Fernando de Rojas has given us "una visión irónica, corrosiva y pesimista de su mundo" $(1969,83)$. 


\section{WORKS CITED}

Ayllón, Cándido. La visión pesimista de 'La Celestina.' México: Ediciones de Andrea, 1965.

Bataillon, Marcel. 'La Célestine' selon Fernando de Rojas. Paris: Didier, 1961.

Beltrán, Luis. "La envidia de Pármeno y la corrupción de Melibea." Insula, 35:398 (enero 1980), 3 and 10.

Brancaforte, Benito. "La estructura moral de La Celestina y El infierno de Dante." Papeles de Son Armadans, 17:196 (1972), 5-22.

Castro, Américo. 'La Celestina' como contienda literaria (castas y casticismos). Madrid: Revista de Occidente, 1965.

Coupe, W. A., A. J. Krailsheimer, J. A. Scott, and R. W. Truman. The Continental Renaissance. Sussex: Harvester Press, 1978.

Deyermond, Alan. "Divisiones socio-económicas, nexos sexuales: la sociedad de Celestina." Celestinesca, 8:2 (Fall 1984), 3-10.

" "Female Societies in Celestina." Fernando de Rojas and Celestina: Approaching the Fifth Centenary. "Proceedings of an International Conference in Commemoration of the 450th Anniversary of the Death of Fernando de Rojas, Purdue University, 21-24 November 1991." Eds. Ivy A. Corfis and Joseph T. Snow. Madison WI: The Hispanic Seminary of Medieval Studies, 1993. 1-31.

Eaton, Katherine. "The Character of Lucrecia in La Celestina." Annali Istituto Orientale Napoli. Sezione Romanza, 15 (1973), 213-25.

Fothergill-Payne, Louise W. "La Celestina como esbozo de una lección maquiavélica." Romanische Forschungen, 81 (1969), 158-75.

Friedman, Edward H. "Rhetoric at Work: Celestina, Melibea, and the Persuasive Arts." Fernando de Rojas and 'Celestina' (see second Deyermond entry). 359-70.

Gallo, Lee A. "Celestina: A New Social Perspective." Medieval Perspectives, 2 (1987), 185-92.

Gilman, Stephen. The Art of 'La Celestina'. Madison: University of Wisconsin Press, 1956.

Gimber, Arno. "Los rufianes de la primera Celestina." Celestinesca, 16:2 (Fall, 1992), 63-76.

Grieve, Patricia E. "Mothers and Daughters in Fifteenth-century Spanish Sentimental Romances: Implications for Celestina." Bulletin of Hispanic Studies, 67 (1990), 345-55.

Hawking, Jane. "Madre Celestina." Annali Istituto Universitario Napoli. Sezione Romanza, 9 (1967), 177-90.

Kish, Kathleen V. Review of Stamm, La estructura (see below). Celestinesca, 14:2 (Fall, 1990), 97-100. 
Lacarra, María Eugenia. Cómo leer 'La Celestina' . Madrid: Ediciones Júcar, 1990.

- "La evolución de la prostitución en la Castilla del siglo XV y la mancebía de Salamanca en tiempos de Fernando de Rojas." Fernando de Rojas and 'Celestina' (see second Deyermond entry). 33-78.

"El fenómeno de la prostitución y sus conexiones con $L a$ Celestina." Historias y ficciones: Coloquio sobre la literatura del siglo $X V$. "Actas del Coloquio Internacional organizado por el Departament de Filologia Espanyola de la Universitat de València, celebrado en Valencia los días 29, 30 y 31 de octubre de 1990." Eds. R. Beltrán, J. L. Canet y J. L. Sirera. Valencia: Universitat de València, 1992. 267-78.

Lida de Malkiel, María Rosa. La originalidad artística de 'La Celestina'. Buenos Aires: Editorial Universitaria de Buenos Aires, 1962.

Lihani, John. "Spanish Urban Life in the Late Fifteenth Century as Seen in Celestina." Celestinesca, 11:2 (November 1987), 21-28.

Mariscal de Rhett, Beatriz. "Los fantasmas de la Libertad en La Celestina." Papeles de Son Armadans, 84:251 (1977), 109-24.

Márquez Villanueva, Francisco. Origenes y sociología del tema celestinesco. Barcelona: Anthropos, 1993.

Morón Arroyo, Ciriaco. Sentido y forma de 'La Celestina'. Madrid: Cátedra, 1974.

Okamura, Hajime. "Lucrecia en el esquema didáctico de Celestina." Celestinesca, 15:1 (Spring, 1991), 53-62.

Rank, Jerry. "Awareness and Reaction: The Underlying Elements of Characterization in the Servants of the Celestina." Kentucky Romance Quarterly, 14 (1972), 223-36.

Ricapito, Joseph V. "People, Characters, and Roles: A View of Characterization in Celestina." Fernando de Rojas and 'Celestina' (see second Deyermond entry). 181-91.

Rodríguez-Puértolas, Julio. "Nueva aproximación a La Celestina." Estudios Filológicos, 5 (1969), 71-90.

"La Celestina o la negación de la negación." Literatura, historia, alienación. Barcelona: Labor Universitaria, 1976. 147-71.

Round, Nicholas G. "Conduct and Values in La Celestina." Mediæval and Renaissance Studies on Spain and Portugal in Honour of P. E. Russell. Eds. F. W. Hodcroft, D. G. Pattison, R. D. F. Pring-Mill, and R. W. Truman. Oxford: The Society for the Study of Mediæval Languages and Literatures, 1981. 38-52.

Sears, Theresa Ann. "Love and the Lure of Chaos: Difference and Disorder in Celestina." Romanic Review, 83 (1992), 94-106.

Shipley, George A. "Authority and Experience in La Celestina." Bulletin of Hispanic Studies, 62 (1985), 95-111. 
Snow, Joseph T. "Una lectura de Celestina-personaje y de la obra de Fernando de Rojas." Historia y ficciones (see above, third entry for Lacarra). 279-87.

Stamm, James R. La estructura de 'La Celestina'. Salamanca: Universidad de Salamanca, 1988.

Tapia, María Cruz Muriel. Antifeminismo y subestimación de la mujer en la literatura medieval castellana. Cáceres: Guadiloba, 1991.

van Beysterveldt, Antony. "Nueva interpretación de La Celestina." Segismundo, 21-22 (1975), 89-116.

Weinberg, F. M. "Aspects of Symbolism in La Celestina." MLN, 86 (1971), 136-53.

\section{Elicia.}

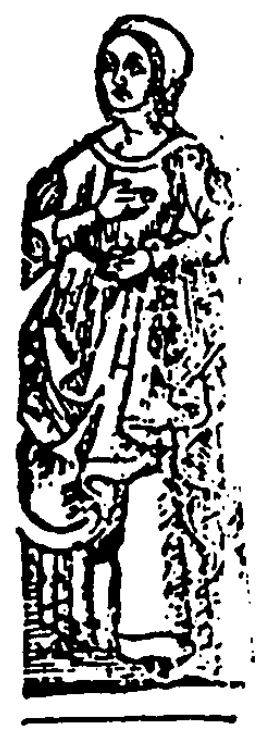

J. Cromberger, Sevilla 1535 


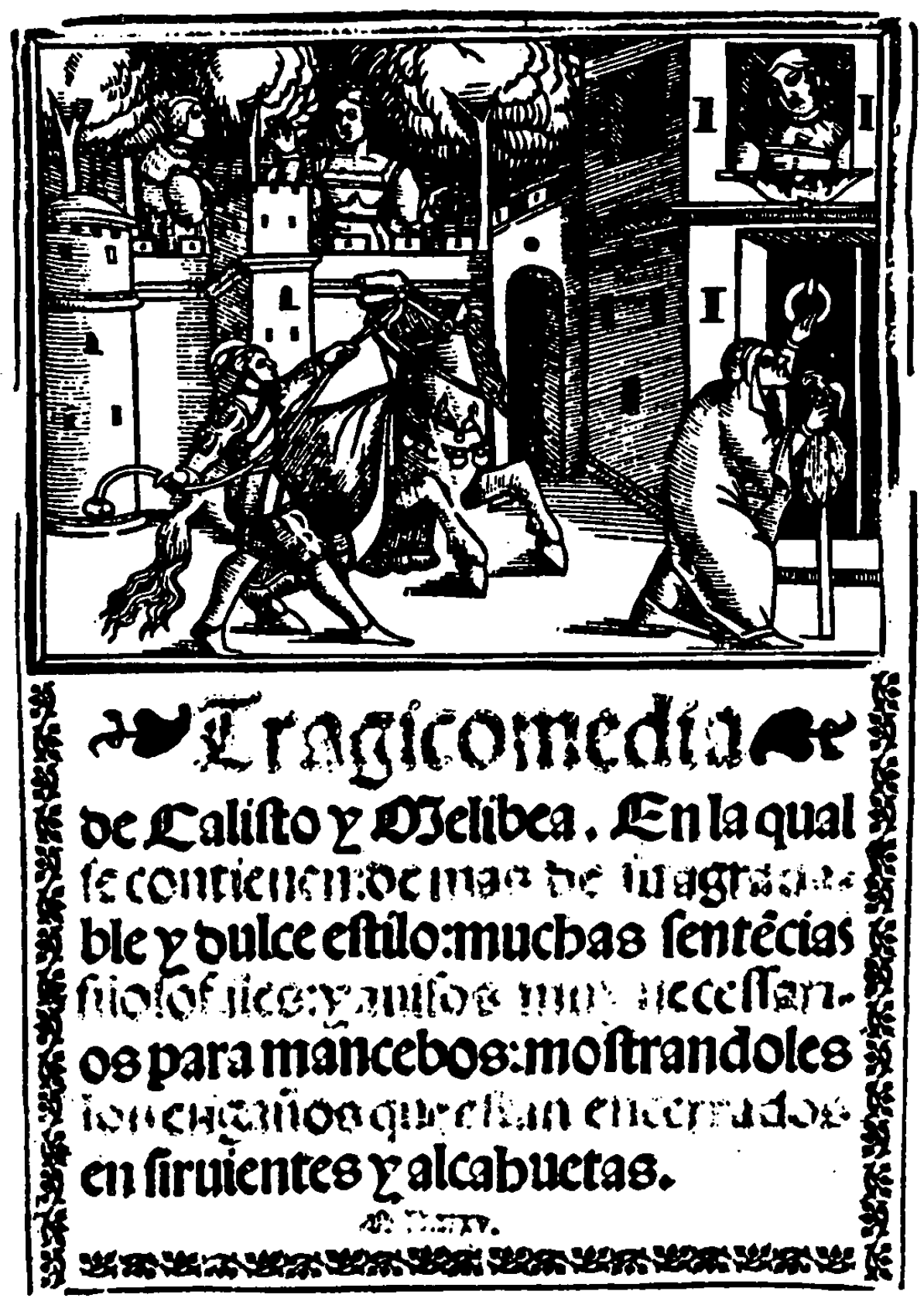

Portada. J. Crouberger, Sevilla 1535 